Aymen Hraiba* Mehmed Ganić** Azra Brankovic ${ }^{* * *}$
JEL Classification F21

Original scientific paper

https://doi.org/10.32910/ep.70.3.3

\title{
DOES THE ARAB SPRING WAVE AFFECT OUTWARD FOREIGN DIRECT INVESTMENT (FDI)? EMPIRICAL EVIDENCE FROM THE MIDEAST AND NORTH AFRICA
}

The paper aims to empirically explore the impact of the Arabic Spring on the outflow of FDI in twelve selected countries in the North Africa region (Algeria, Tunisia, Morocco, Libya, Egypt and Mauritania) and the Mideast region (Bahrain, Kuwait, Oman, Lebanon, Jordan and the United Arab Emirates). The paper employs a panel data approach to exploit the time series nature of the relationship between FDI Outwards and its determinants (the market size, trade openness, government effectiveness, inflation and three dummy variables related to the Arab Spring) between 2000 and 2016. The findings revealed that the impact of the Arab Spring estimator is negatively correlated with FDI Outflows in the countries that witnessed the Arab Spring. It implies that conflicts and instability negatively affect FDI outflows. The findings of this study reveal that countries that have been affected by the Arab Spring directly (the North Africa region) experienced a greater decline of FDI outflows than countries that have been indirectly affected (the Mideast region). When the sample is restricted to North Africa

* A. Hraiba, MA, Faculty of Business Administration, International University of Sarajevo, Bosnia and Herzegovina (E-mail: hriba1989@gmail.com).

** M. Ganić, Ph.D., Associate Professor, Faculty of Business Administration, IUS, Bosnia and Herzegovina (E-mail: mganic@ius.edu.ba).

${ }^{* * *}$ A. Branković, Ph.D., Assistant Professor, Faculty of Business Administration, IUS, Bosnia and Herzegovina (E-mail: abrankovic@ius.edu.ba).

The paper was received on September 29th, 2018. It was accepted for publication on March 12th, 2019. 
it is shown that the FDI outflows may be influenced by the post Arab Spring effect, while there is no such statistically significant effect in the Mideast region. Thus, the study finds that FDI outflows in the North African countries are more determined by the effects of Arabic Spring countries than in the Mideastern countries.

Keywords: FDI outflows, the Arab spring, Mideast and North Africa, panel data analysis

\section{Introduction}

Many existing empirical studies explore FDI inflows in the host country, while FDI outflows from the home country is less studied. The economy of Arab countries is characterized by a number of factors that have adversely affected their economic performance in recent years, such as the drop in the price of oil and the slow recovery of the global economy. Moreover, the region has undergone political changes and protests as the result of the Arab spring that spread across the region in early 2011. This gives a great incentive for further investigation of this political phenomenon in the region.

Related to this, in many developing countries, especially the Arab countries, the topic of FDI outflows is important, because of the large exports of FDI from oil producing countries. Accordingly, the study aims to explore how Outward FDI in the Mideast and North Africa has been affected by the Arab Spring.

Today, the numerous FDI studies focusing on the Mideast and North Africa (Bashir, 1999; Cardak and Moosa, 2006; Ben-Taher and Giorgione, 2009) reveal that the most attention is paid to FDI inflows and the role of the host country, while FDI outflow studies about the determinants of the home country are very limited.

Furthermore, the region experienced a period of transition and political changes in recent years after the Arab spring. The crucial question here is to examine whether the Arab Spring impacts foreign investment preference in the Mideast and North Africa countries. So, the research may provide benefit to decision and investment policy makers in the Mideast and North Africa. Previous empirical studies that widely examined determinants of FDI outflows ignored the developing countries and entire regions in the Arab world. In addition, the Arabic world witnessed the wave of recent changes across the region in early 2011, while there is a lack of consensus regarding the role of institutional factors. In this context, the research is based on examining the effects of the Arab spring on outflows of FDI in the Mideast and North African countries. The paper adopts a panel data estimation methods and empirically tests a hypothesis of negative effect of the 
Arab Spring on outflows of FDI in the Mideast and North Africa countries. With the point of FDI outflows, the Arab region is characterized by certain volatility. Taken together, the whole region experienced rise of FDI outflows slightly after the Arab Spring. In the last eleven years measured by mean of FDI outflows for each country in our sample, we found that Kuwait is a leader in FDI outflows, followed by Qatar, while Tunisia and Algeria are ranked as the last in terms of FDI outflows. Generally speaking, the Arab world as a whole experienced decline of FDI flows from $3.33 \%$ of GDP (2010) to $1.57 \%$ of GDP (2016). According to UNCTAD (2016), outflows of FDI increased from Libya and Morocco while outflows FDI from the Maghreb region fell by $6 \%$. In contrast, there was a rise in FDI outflows from some other oil producing countries and oil-exporting countries, including Qatar with 96 percent .

The structure of this paper includes the introduction section by presenting the aim and problem of research. In the literature review section, some of the FDI's theories and recently conduction empirical studies about FDI outflows are examined and presented. The third section explains the methodology and specifation model used in this study. The main empirical findings of the research will be given in the section four. The research ends with the conclusions and a list of the recommendations.

\section{Literature review}

In the last few decades, scholars intensively retraced the FDI thought steps and utilized much FDI-related empirical research to examine the growth of crossborder FDI flows.

The FDI outflow theories take the same direction as the FDI inflow theories. Generally speaking, investigation of FDI inflows is related to the host country's determinants while an investigation of FDI outflows is related to the home country's determinants. Notwithstanding the limitation of studies on FDI outflows in Arab countries, the research presents a number of studies conducted around the world on FDI outflows.

Collier (1999) believes that a civil war causes the escape of resources (financial, physical and human capital) to other safer locations. From the perspective of FDI, a civil conflict is an obstacle to the risk-averse international investor. However, Collier's theory doesn't explore the economic effects of external conflicts. He suggests that "the breakdown of social order and the absence of a clear front line are more common to civil war than to international war" (Collier, 1999), and that these disruptions imply higher economic costs. There are plenty of stud- 
ies that investigate the determinants of FDI outflows in other places. Furthermore, the region experienced a period of transition and political changes in recent years after the Arabic spring. The crucial question here is to examine whether the Arab spring changes foreign investment preference in the selected Arab countries. So, the research may provide benefit to decision and investment policy makers in the Mideast and North Africa. Previous empirical studies that widely researched determinants of FDI outflows ignored the developing countries and entire regions in the Arab world.

Yarbrough and Yarbrough (2002) explain how companies establish their FDI in locations that have the most noteworthy potential for benefit and minimum risks. The essential theory related to FDI is expanded in a paper by Schneider and Frey (1985) who accentuate the requirement for a model that consolidates both economic and political determinants. Schneider and Frey (1985) and Buckley (2007) argued the importance of political risk in relation to a good investment climate, as it can influence the country's political landscape. This can indicate that a high level of political instability makes the host country less attractive to foreign investors, as uncertainty about future events makes the investment more risky.

In their research Hill and Jongwanich (2009) investigated the position of East Asian economies in a period of large external shocks (the Asian Financial Crisis and the Global Financial Crisis) and their relationship to FDI outflows. The study reveals that FDI behavior in East Asian countries is highly determined by country-specific characteristics that have substantial and unpredictable impact.

Other scholars, Kyrkilis and Pantelidis (2003) empirically explore macroeconomic characteristics of nine countries (France, Germany, Italy, The Netherlands, UK from EU countries and Korea, Brazil, Singapore and Argentina as not EU countries) and measure their impact on FDI outflows. The study covers a period of twenty years from 1977 to 1997. They found that the FDI outflows are strongly determined by income. Furthermore, the importance of their relationship varies for the same type of endowments from country to country and from region to region. Frenkel et al., (2004) explored home and host country's factors of FDI flows by using a panel approach in the case of host countries (emerging economies in Asia, Latin American, and Central and Eastern Europe). The study found some variables as: market size, risk, distance, economic growth as the main drivers of attraction of FDI inflows.

Saime (2009) explored home market determinants of FDI outflows for 65 developing and transition countries (12 from Africa, 16 from America, 23 from Asia and 14 transition countries) between 2000-2006. The study examines the costs of production local business conditions and small market size as motives for outflows of FDI. The study found that outward FDI from these countries is significantly determined by the level of economic development, infrastructure and labor mar- 
ket conditions. Similarly, Garoni (2015) investigated institutional determinants of outflows of FDI, examining how institutional variables affect decisions about outflows of FDI in Latin American countries between 2006 and 2013. The study followed a quantitative approach looking for a potential correlation between outflows of FDI and institutional variables such as capital market efficiency, product market efficiency or government efficiency. His findings show mixed effects for different countries, depending on their resource endowments, size and industry background that seem to have varying effects on outward FDI throughout the countries. Surprisingly, a negative correlation between FDI outflows and institutional factors is found as in the case of capital market efficiency.

Wang (2017) explored the home-country determinants of outward FDI for five BRICS countries (Brazil, Russia, India, China and South Africa) and five developed countries (US, UK, Germany, Australia and Japan) between 1996 and 2014. The research concludes that the size of the market in the home country was found to have a significant positive effect on FDI outflows. However, when the same estimates were used in the two country groups the variable of market size is shown as negligible while the interest rate has a significant positive impact. Also, inflation has a statistically significant and negative effect on FDI outflows, while lower levels of political risk reduce the likelihood of political instability that leads to decline of FDI outflows. The openness of the home country is boosting both inward and outward FDI. Two variables, exchange rate and corruption were found as statistically significant only in the BRICS countries, but not for the full sample.

As indicated above, political (in)stability can play an essential role in determination of FDI outflows, but this does not necessarily have to be the rule. Many developing countries, such as the Arab countries have not been properly analyzed in terms of the Arab spring's impact on FDI outflows. Therefore, the study takes the effect of Arab spring into account in order to examine its contribution to FDI outflows. Accordingly, our research seeks to address some of the lacunae in the existing literature by introducing three new dummy variables that have yet to be examined.

To sum up, the results of the literature review show that there are various determinants of FDI outflows between developing and developed countries. The study followed a quantitative approach looking for a potential correlation between outflows of FDI and institutional variables such as capital market efficiency, product market efficiency or government efficiency. The findings show mixed effects for different countries, depending on their resource endowments, size and industry background that seem to affect outward FDI differently throughout the countries. Surprisingly, a negative correlation between FDI outflows and institutional factors as in the case of capital market efficiency is found. At the same time the review of the literature shows us that there is not any empirical study available attempting to explore the effects of the Arab spring on FDI outflows. 


\section{Research Methodology}

\subsection{Data}

The study comprises an annual data set of twelve countries in the Mideast and North Africa countries collected between 2000 and 2016. The sample of home countries and time period are mainly determined by the available data. The research covers twelve countries from the Mideast and North Africa, including Algeria, Tunisia, Morocco, Libya, Egypt and Mauritania from the North Africa region and Bahrain, Kuwait, Oman, Lebanon, Jordan and the United Arab Emirates. Thus, the country-based analysis may provide a preliminary understanding of the relationship between the determinants of the home country and outflow of FDI. Furthermore, it is worth considering whether the drivers of FDI outflows are the same among countries. This study used a quantitative approach and sourced the data from Global Insight - Global Risk Service, World Bank database and the IMF database between 2000 and 2016.

\subsection{Determinants of FDI}

According to the theories on FDI and previous studies related to FDI outflows, the study explores how devastating the Arab Spring has been to Outward FDI in twelve countries of the Mideast and North Africa. As possible proxy variables in the model, whose impact on FDI inflows is planned to be tested, we propose the variables described bellow, similar to the ones used by some previous studies (Das, 2013; Kyrkilis and Pantelidis, 2003), but while introducing a few new variables related to the Arab spring.

\section{Market Size}

The GDP per capita is included as a proxy variable to measure market size. Many previous empirical studies (Frenkel et al., 2004; Amal, et al., 2009; Kyrkilis and Pantelidis, 2003; and other scholars) reveal the size of the market as a statistically significant determinant of FDI outflow. It means that a country that has a larger market tends to have a significant reserve of capital and intangible assets, thus having more investment capital to expand production more easily. In addition, 
some previous studies indicate that the size of the country of origin is positively associated with external FDI (Tallman, 1988 and Grosse and Trevino, 1996). Also, Kyrkilis and Pantelidies (2003) and Wang (2017) found market size to have significant and positive effects on FDI outflows. In anyway, it is expected that market size affects FDI outflows positively.

\section{Inflation}

Along with market size, the impact of macroeconomic stability is also accounted in the study. The variable inflation is another determinant that also affects a country's outflow of FDI. Many previous studies confirm that high inflation in the host country impedes FDI inflows (Okafor, 2015; Thomas and Grosse, 2001; Pradhan and Saha, 2011). It is interesting, that a high inflation rate in the home country reflects the failure of macroeconomic policies that affect market stability and lead to a negative business climate. Within an empirical study by Sung and Lapan (2000) carried out among multinational companies they purposed to clarify the relationship between strategic FDI and macroeconomic uncertainty. The study found that inflation has a significant impact on developing countries, but not as much on developed countries. In his study, Wang (2017) found that inflation has significant negative effects on FDI outflows. Moreover, the rate of inflation is linked to the reduction of costs in order to engage in FDI in relation to the selective Dunning's model $(1977 ; 1979)$. The study supposes that the variable Inflation affects negatively FDI outflows.

\section{Trade Openness}

Inclusion of Trade Openness is based on evidence of some researchers (Kyrkilis and Pantelidis, 2003; Banga, 2007; Nielsen and Hällås, 2015) that found the openness of the economy as the most important variable affecting FDI outflows. Empirical studies (Buckley, 2007 and Das, 2013) generally indicate a positive relationship between the level of trade openness and FDI inflows. Moreover, openness of the home country was found to be beneficial to both inflows and outflows of FDI (Wang, 2017). Accordingly, it is expected that trade openness positively influence FDI outflows. 


\section{Government efficiency}

To examine whether the level of FDI outflows in selected host countries is influenced by lower or higher level of government efficiency, the proxy variable Quality of public and civil service is included. Mauro (2010) investigated the importance of regulations and rules for investment, which could cause outward FDI. Also, higher government efficiency in the host country reduces significantly transaction costs and uncertainty. Similarly, the efficiency of government promotion activities (Wang et al., 2012), such as the signing of free trade agreements with other countries or economic blocs (Thangavelu and Findlay, 2011), have overall and significant effect on FDI outflows. Government policy and the extent to which it encourages outflows ofFDI directly affect the volume of outflows.

\section{Arab Spring}

Rationale for inclusion of the Arab Spring in our model is its effect on economic trends throughout the Arab countries. Theoretically, there is some evidence provided by Cobham and Zouache (2015) andAlsoudi, (2014) that the Arab Spring is indirectly impacting changes in FDI flows. A common method of accounting for the Arab Spring has been to employs three dummy variables. In this study we take a somewhat different approach. The Arab region witnessed a dangerous political turn in the form of mass movements and protests that began in Tunisia (in late 2010) and spread throughout the Middle East and the North Africa region and became known as the Arab Spring. Some Arab countries have experienced a wave of political change since the outbreak of the revolution and protest movements against the Arab regimes. Political change came to Tunisia, Egypt, Libya, and Yemen, in various forms, ranging from the limited scope of war to universal eligibility, including taking the peaceful form away from change and direction.

Since then, there have been strikes and conflicts in some of these countries, such as Libya, Syria, and Yemen, while other such as Tunisia, Egypt, and Bahrain have achieved some sort of political stability. Several studies have been performed on the impact of the Arab Spring on political, economic, social and other topics. Cobham and Zouache (2015) investigate the impact of the Arab Spring on Economic Features, while Alsoudi (2014) measured the impact of the Arab Spring on the Political Future of the Muslim Brotherhood in the Middle East. A negative relationship between the Arab Spring and outward FDI is expected. 
A. HRAIBA, M. GANIĆ, A. BRANKOVIĆ: Does the Arab spring wave affect outward foreign direct investment (FDI)?...

EKONOMSKI PREGLED, 70 (3) 411-430 (2019)

\subsection{The Model specification}

Taking into consideration all discussed determinants, the theoretical model of the determinants of outward FDI in Arab countries is presented, where i stands for country observed, and t for year observed. We follow the empirical research and a model developed by Das (2013), Tallman (1988), slightly modified with control variables and extended by some new dummy variables.

FDI Outflow it $=\mathrm{f}$ (Market size it, Trade openness it, Inflation it, Government efficiency it, Arab Spring it).

Each country from the sample is a different entity. According to availability of data, the time period between 2000 and 2016 will be covered and the countries are divided in two subpanels: the North Africa region (has been affected by the Arab Spring directly) and the Mideast region (has been affected by the Arab Spring indirectly). Thereafter, a panel data analysis helps us to exploit the time series nature of the relationship between FDI Outflow and its determinants for the selected Arab countries. The econometric model in this research includes a set of control variables and three dummy variables related to the Arab Spring as shown in equation 1

$$
\begin{aligned}
\text { OFDIit }= & \alpha+\beta 1 \text { GDPPC it }+\beta 2 \text { INFLit }+\beta 3 \text { TROit }+\beta 4 \text { GOVE it }+ \\
& +\beta 5 \text { Uprising it }+\beta 6 \text { Border it }+ \text { Time it }+\mathrm{u} \text { it }
\end{aligned}
$$

Where:

FDI outflow (OFDI) is a dependent variable denoting net outflow as percentage of GDP.

GDP per capita (GDPPC) is used as a proxy variable to measure the effect of market size

The variable Inflation (INFL) expressed by average consumer prices is employed to measure macroeconomic stability.

The variable Trade openness (TRO) is expressed as ratio of total trade to GDP to measure the openness of country.

The variable Government effectiveness (GOVE) is proxied by the quality of public and civil service to measure quality of Government effectiveness.

Uprising is a dummy variable taking the value 1 if a country experienced a civil war, revolution or sustained civil disorder from 2011, otherwise $=0$.

Border is a dummy variable, taking the value 1 if a country has borders with countries that experienced the Arabic spring from 2011, otherwise $=0$. 
Time is a dummy variable, taking the value 1 if the period in question is from 2011 to 2016, otherwise $=0$.

The research employs the dummies according to the events of Arabic spring.

\subsection{Data models}

In many cases, three models are most commonly used to process the panel data. First is the Pooled Regression Model as the simplest model for panel data processing. It can be found under the name of the population averaged model as well, assuming that any latent heterogeneity has been averaged out (Greene, 2012). The model uses Ordinary least squares as the estimator with the assumption that all other assumptions of linear model are met. The first pooled regression model employs constant coefficients, as a common assumption for cross-sectional analysis

$$
\mathrm{OFDI}_{\mathrm{it}}=\alpha+\mathrm{x}_{\mathrm{it}} \beta+\mu_{\mathrm{it}}
$$

Where index $i=1 \ldots 12$ symbolizes a selected country of the Arab world and $\mathrm{t}=2000-2016$ symbolizes time in terms of different years.

$\mathrm{F}_{\mathrm{it}}$ is Foreign direct investment outflows (OFDI) as a \% of GDP of the country " $\mathrm{i}$ " in a year " $\mathrm{t}$ " and is the dependent variable, while " $\mathrm{x}_{\mathrm{it}}$ " expresses the value of independent variables $(K \times 1$ vector) for the country "i" in a year " $t$ ". $\beta$ is a $K \times 1$ parameter vector, while $\alpha$ is the intercept, and is the usual disturbance term.

The secondis the Fixed Effects Model (FE model) used, in some cases, to control omitted variables that may vary across countries but do not change over time. Some possible changes in a dependent variable may be the result of other influences, but no changes in fixed characteristics (Stock, 2012). The FE model uses the individual-specific effects $\alpha i$ to be correlated with the regressors $\mathrm{x}$.

$$
\mathrm{OFDI}_{\mathrm{it}}=\alpha i+\mathrm{x}_{\mathrm{it}} \beta+\mu_{\mathrm{it}}
$$

Under the Random Effects Model (RE model) variation across countries is random and it is not correlated with the independent variables (Greene, 2012). The $\mathrm{RE}$ model begins with an assumption that the regressors do not correlate with the individual-specific effects $\alpha i$. The same slope parameters and a composite error term have each individual $\varepsilon i t=\alpha i+e_{i t}$. 


$$
\mathrm{OFDI}_{\mathrm{it}}=\mathrm{x}_{\mathrm{it}} \beta+\left(\alpha i+\mathrm{e}_{\mathrm{it}}\right)
$$

To decide between the Pooled Model, FE model or RE model some diagnostic tests should be done (F-test, LM test and Hausman test). To choose between the $\mathrm{FE}$ and the RE, the Hausman specification test is performed. The Breusch-Pagan LM test of independence or Pasaran CD test is applied to test cross-sectional dependence/contemporaneous correlation (Baltagi, 2008).

\section{Empirical findings}

The correlation matrix showed in Table 1 is used to present a rudimentary check for multicollinearity. The matrix illustrates the data distribution of our variables. It becomes a potential issue when independent variables in a regression are highly correlated with each other. Multicollinearity can be a problem if the correlation between two variables exceeds 0.80 (Field, 2005). In our case, Table 1 shows that there is a moderate degree of collinearity between the variables. Three correlation's pairs with control variables are below 0.80. Additionally, the mean value of the VIF test is 1.64 and the value does not exceed the threshold of 2 for any variable individually (Appendix: B). In anyway, this implies an absence of a serious multicolinearity problem.

Table 1.

\section{CORRELATION MATRIX}

\begin{tabular}{|c|c|c|c|c|c|c|c|c|}
\hline & OFDI & INFL & GDPPC & TRO & GOVE & $\begin{array}{c}\text { Time- } \\
\text { Dummy }\end{array}$ & $\begin{array}{c}\text { Uprisi- } \\
\text { Dummy }\end{array}$ & $\begin{array}{c}\text { Border- } \\
\text { Dummy }\end{array}$ \\
\hline OFDI & 1 & & & & & & & \\
\hline INFL & 0.0435 & 1 & & & & & & \\
\hline GDPPC & 0.3214 & -0.0214 & 1 & & & & & \\
\hline TRO & 0.0865 & -0.0621 & 0.5576 & 1 & & & & \\
\hline GOVE & 0.0457 & -0.1299 & 0.6085 & 0.5371 & 1 & & & \\
\hline TimeDummy & -0.0118 & 0.0569 & 0.195 & 0.1663 & 0.0692 & 1 & & \\
\hline UprisiDummy & -0.1687 & 0.2274 & -0.0257 & 0.0645 & -0.0343 & 0.4847 & 1 & \\
\hline BorderDummy & 0.0163 & 0.0398 & -0.0786 & -0.1634 & -0.1452 & 0.3776 & -0.0865 & 1 \\
\hline
\end{tabular}

Source: Authors' estimation 
Before we decide which model is more appropriate, some tests are employed (F test, Breusch Pagan and Hausman and others) to determine which model accurately represents our data. The serial autocorrelation in the model is examined by employing the Wooldrige test $(\mathrm{F}=1.104$ with $\mathrm{Prob}>\mathrm{F}$ equal to 0.3160$)$ as shown in Appendix C. The findings of the Wooldrige test didn't find a problem of serial correlation. However, the findings of the Breusch-Pagan/Cook-Weisberg test for heteroscedasticity $(\operatorname{chi} 2(1)=20.85$ and Prob $>$ chi $2=0.0000)$ provide evidence that the model is heteroscedastic. In addition, it can be concluded from our results (Table 2) that the RE model will be better suitable and efficient than the FE model for measuring changes in FDI Outflows.

Table 2.

\section{MODEL SELECTION}

\begin{tabular}{|l|l|l|l|}
\hline Pooled vs Fixed & F test that all $\mathrm{u}_{-} \mathrm{i}=0$ & $\mathrm{~F}(11.171)=5.61$ & Prob $>\mathrm{F}=0.000$ \\
\hline Pooled vs Random & $\begin{array}{l}\text { Breusch and pagan } \\
\text { Lagrangian multiplier test }\end{array}$ & chibar2(01)=37.54 & $\begin{array}{l}\text { Prob }>\text { chibar2 } \\
=0.0000\end{array}$ \\
\hline Random vs Fixed & Hausman Test & chi2( 6)=10.57 & Prob $>$ chi22 $=0.1028$ \\
\hline
\end{tabular}

Source: Authors' estimation

To solve possible problems related to heteroskedasticity of unknown form, "robust" option is used to adjust standard errors and control the problem of heteroscedasticity.

Table 3 presents comparative results of regression models for the full sample and two subpanels. The overall R-square of the regression for the full sample is $16 \%$, while $65 \%$ and $13 \%$ have been observed for the North Africa countries and the Mideast countries, respectively. The significance and the coefficients of the variables in the presented panel models vary among themselves. 
A. HRAIBA, M. GANIĆ, A. BRANKOVIĆ: Does the Arab spring wave affect outward foreign direct investment (FDI)?... EKONOMSKI PREGLED, 70 (3) 411-430 (2019)

Table 3.

COMPARING ESTIMATORS FOR PANEL DATA MODEL

\begin{tabular}{|l|c|c|c|}
\hline & (Subpanel 1) & (Subpanel 2) & (Full sample) \\
\hline GDPPC & 0.0003257 & 0.0000939 & 0.0001 \\
\hline TRO & $(4.53)^{* * *}$ & -1.07 & $(1.66)^{*}$ \\
\hline & -0.0003361 & -0.0057226 & -0.003 \\
\hline GOVE & $(-0.18)$ & $(-0.25)$ & $(-0.41)$ \\
\hline & -0.4273483 & -6.793315 & -3.793 \\
\hline INFL & $(-0.57)$ & $(-1.81)^{*}$ & $(-2.90)^{* * *}$ \\
\hline & 0.0801123 & 0.0237804 & 0.117 \\
\hline Uprising Dummy & $(1.90)^{*}$ & $(0.27)$ & $(3.14)^{* * *}$ \\
\hline & -1.246094 & -2.620104 & -2.62 \\
\hline Border Dummy & $(-2.84)^{* * *}$ & $(-2.31)^{* *}$ & $(-2.06)^{* *}$ \\
\hline & -1.42157 & -0.5053367 & -0.744 \\
\hline Time Dummy & $(-3.74)^{* * *}$ & $(-0.31)$ & $(-2.65)^{* * *}$ \\
\hline & 0.3362466 & 0.0697069 & 0.322 \\
\hline sigma_u & $(1.91)^{*}$ & -0.05 & -1.28 \\
\hline sigma_e & 0 & 0 & 1.39 \\
\hline Rho & 0.55071751 & 2.8266348 & 2.13 \\
\hline R- squared & 0 & 0 & 0.29 \\
\hline R- squared within & 0.65 & 0.13 & 0.16 \\
\hline R- squared between & 0.55 & 0.18 & 0.18 \\
\hline ISwpris & 0.94 & 0.19 & 0.26 \\
\hline
\end{tabular}

1 Subpanel 1: Algeria, Tunisia, Morocco, Libya, Egypt, Mauritania

2 Subpanel 2: Bahrain, Kuwait, Oman, Lebanon, Jordan and the United Arab Emirates

3 Full Panel: Algeria, Tunisia, Morocco, Libya, Egypt, Mauritania, Bahrain, Kuwait, Oman, Lebanon, Jordan and the United Arab Emirates

Source: Authors' calculation (*** Statistically significant at the $1 \%$ level, ** Statistically significant at the $5 \%$ level, $*$ Statistically significant at the $10 \%$ level).

It is interesting that the findings are both similar for the full sample and the North Africa countries. Five variables from our full sample are shown as statistically significant for FDI outflows (market size, uprising dummy, border dummy, inflation and government effectiveness) and the North Africa countries (market size, uprising dummy, border dummy, time dummy and inflation). On the contrary, only two variables are shown as statistical significant in the Mideast countries (government effectiveness and uprising dummy). 
The study employed an uprising variable and found it to be $1 \%$ statistically significant in the North African countries and 5\% for the whole sample and the Mideast countries, in explaining FDI outflows. For the whole sample and the two subpanels the evidence suggests that conflicts and instability had a negative effect and lead to reduced FDI outflows. The uprising variable provided stronger explanatory power than the other two dummy variables.

Furthermore, the border dummy variable has a negative effect on FDI outflows. This is true for the full sample and the North African countries, where it ishighly significant (at 1\%). This is in line with our expectations. The same is not true for the Mideastern countries. When the sample is restricted to the North Africa FDI outflows, it may be influenced by the post Arab Spring affect. On the other hand, we couldtnot find any such effect if the sample was restricted to the Mideastern countries or for the whole sample.

The control variable market size was found to be statistically significant at $10 \%$ and $1 \%$ with a positive coefficient in determination of FDI outflows (in the case of full sample and North African countries). This may be explained by the fact that the large market size of the home country is more likely to increase FDI outflow. This finding supports our expectation regarding market size. Also, it is consistent with some literature findings includingWang (2017), Tallman (1988) and Grosse and Trevino (1996).

In addition, the control variables: inflation and government effectiveness were also found to be statistically significant at $1 \%$ in case of the whole sample. We found that inflation affects FDI outflows positively. Our finding is in line with some previous studies done by Sung (2000). Also, the control variable government effectiveness negatively affects FDI outflows which support our expectations for the full sample and the Mideast countries. If the sample is restricted to the North African countries it is shown as insignificant. The failure of the government to perform its duties effectively would decrease FDI outflows. On the contrary, if a govermant improves its quality of services, both may see increased FDI outflows. This finding also cooresponds to other studies such as Thangavelu and Findlay (2011), Mauro (2010) and Soo and Wong (2010).

The study included other explanatory variables expected to have a correlation with FDI outflows. However, the results showed the opposite. For example, there is no evidence that the variable Trade openness is statistically significant. It is opposite to the findings of previous studies, as the oneby Nielsen and Hällås (2015). 
A. HRAIBA, M. GANIĆ, A. BRANKOVIĆ: Does the Arab spring wave affect outward foreign direct investment (FDI)?... EKONOMSKI PREGLED, 70 (3) 411-430 (2019)

\section{Conclusion}

This paper examines the impacts of the Arab spring on FDI outflows. The number of independent variables analyzed in our sample was selected becasue they have been shown to be statistically significant in certain previous studies. The study could not find or confirm that all the independent and control variables employed in the regression model have an important role in the explanation of the variance of FDI outflows. This implies that the movements in FDI outflows are determined by some other factors that are relevant for developing countries. In line with some expectations, our findings confirm the importance of the Arab Spring for outflows of FDI, as well as of some control variables (inflation and government), specially in the North Africa region, while the post Arabic Spring effect is not significant in the Mideast region. Moreover, the study couldn't find evidence that a change in trade openness affects changes in the structure of the FDI outflows. There is little indication that FDI outflows are determined by macroeconomic and institutional variables.

There is some evidence that the impact of the Arab Spring estimator is negatively correlated with FDI outflows in the countries that witnessed the Arab Spring (the North Africa region and the Mideast region). This implies that conflicts and instability negatively effect FDI outflows. Moreover, the effect extends to neighboring countries, although the Arab Spring does not affect FDI outflows in all of the Arabic world. A more interesting point of this study is that countries that have been affected by the Arab Spring directly (the North Africa region) experienced more decline of FDI outflows than the indirectly affected countries (the Mideast region).

Thus, as seen from our findings the effects of the Arab Spring since 2011 on FDI outflows in the hit countries have been clear, in addition to the transmission of these effects to neighboring countries. Countries that are located in the same region without a common border with the spring countries settled away from these influences on the investment environment. The above results naturally suggest that specific reform policies are important for policy makers in attempting to improve the investment environment. The new regimes established following the Arab Spring urge for transparent reforms in institutions. One of the main objectives should be related to achieving a level of stability and certainty. In addition to maintaining appropriate inflation rates and emphasize the role of government effectiveness. Moreover, these findings are a little different from our model's expectations and require further examination. They should be directed to further extension, especially in terms of the detailed disaggregation of data on the FDI outflows. Further, there are significant differences between some Arab economies. Some are stable. While others are degraded, which may create some problems. 
That indicates the sample should be convergent. Finally, the Arab Spring strikes are still going on in some countries, while they have almost stopped in others. For future research it would be interesting to explore the characteristics of each country.

\section{References}

Amal, M., Raboch, H., and Tomio, B. (2009). Strategies and Determinants of Foreign Direct Investment (FDI) from Developing Countries: Case Study of Latin America, Latin American Business Review, 10: 73-94.

Alsoudi, D. A. (2014). The Impact of Arab Spring on the Political Future of the Muslim Brotherhood in the Middle East:Jordan as a Case Study. Journal of Islamic Thought and Civilization, Volume 4, Issue I. Retrived from http:// www.rubincenter.org/2016/02/the-impact-of-the-arab-spring-on-the-political-future-of-the-muslim-brotherhood-in-the-middle-east-jordan-as-a-casestudy/

Banga, R. (2007), Explaining Asian Outward FDI. Paper presented at ARTNeT Consultative Meeting on Trade and Investment Policy Coordination, Bangkok 2007. Retreived from http://www.unescap.org/tid/artnet/mtg/tipc_s6banga.pdf on 11th March 2013

Baltagi, B. (2008). Econometric Analysis of Panel Data, Third Issue, John Wiley \& Sons Ltd.

Bashir, A.M. (1999). Foreign Direct Investment and Economic Growth in Some MENA Countries: Theory and Evidence. Topics in Middle Eastern and North African Economies. Paper 9. Retreived from https://pdfs.semanticscholar. org/c429/728202e184b77eed10bbe2d6ef0b8fd43e33.pdf

Ben-Taher, H. and Giorgioni, G. (2009). Impacts of Foreign Direct Investment on Economic Growth: A Panel Data Study for the AMU Countries. Center of International Banking, Economics, and Finance Working paper.

Buckley, P. J. (2007). The determinants of Chinese outward foreign direct investment. Journal of international business studies, 38(4) , 499-518. Retrived from: https://www.jstor.org/stable/4540439

Cardak, B.A. and Moosa, I. (2006) . The Determinants of Foreign Direct Investment. Journal of Multinational Financial Management 16(2):199-211 DOI: 10.1016/j.mulfin.2005.07.002

Cobham, D. and Zouache, A. (2015). ECONOMIC FEATURES OF THE ARAB SPRING. The Economic Research Forum (ERF) NO.975. Retrived from https://erf.org.eg/wp-content/uploads/2015/12/975.pdf 
Collier, P. (1999). On the economic consequences of civil war, Oxford Economic Papers, Vol. 51, No. 1.

Das, Ch. Khanindra. (2013). Home Country Determinants of Outward FDI from Developing Countries. Margin-The Journal of Applied Economic Research. Vol 7, Issue 1, 2013.Retrived from http://journals.sagepub.com/doi/ abs/10.1177/0973801012466104.

Dunning, J. H. (1977). Trade, location of economic activity and the MNE: a search for an eclectic approach. London: Holmes and Meier.

Dunning, J. H. (1979). Explaining changing patterns of international production: In defense of the eclectic theory. Oxford Bulletin of Economics \& Statistics, 41, 269-295.

Field, A. (2005). Discovering statistics using SPSS. London: Sage Publications Ltd.

Fielding, D. (2004). How Does Violent Conflict Affect Investment Location Decisions: Evidence from Israel During the Intifada. Journal of Peace Research, Vol. 41. Retrived from https://www.prio.org/JPR/Datasets/

Frenkel, M., Funke, K. and Stadtmann, G. (2004). A Panel Analysis of Bilateral FDI Flows to Emerging Economies, Economic Systems, 28: 281-300.

Garoni, S. (2015). Institutional determinants of outward foreign direct investment in Latin America. Business and Development Studies. BADS. Frederiksberg. Retrived from http://hdl.handle.net/10417/5696.

Greene, W. (2012). Econometric Analysis. Upper Saddle River, New Jersey 07458: Pearson Education Limited.

Grog and Greenaway. (2004). Much ado about nothing? Do domestic firms really benefit from foreign direct investment? World Bank Research Observer. Retrived from https:/elibrary.worldbank.org/doi/pdf/10.1093/wbro/lkh019.

Grosse, R. and Trevino, L.J. (1996 ). Foreign direct investment in the United States: An analysis by country of origin. Journal of international business studies, 27(1), 139-155.

Hill, H.and Jongwanich,J. (2009). Outward Foreign Direct Investment and the Financial Crisis in Developing East Asia. Asian Development Review: Studies of Asian and Pacific Economic Issues, 26(2), 1-25. Retrived from https://pdfs. semanticscholar.org/94fc/8dec29ac4d21a1442ab628afb6b26183fd5a.pdf

Kyrkilis, D. and Pantelidis, P. (2003) Macroeconomic determinants of outward foreign direct investment. International Journal of Social Economics, 30, 827- 837.

Mauro, R. (2010). Import substitution and economic growth. Journal of Monetary Economics 57(2), 175- 188. 
Nielsen, C. and Hällås, K. (2015). Macroeconomic Determinants of European FDI Outflows. University of Gothenburg. Retrived from https://gupea.ub.gu. se/bitstream/2077/40588/1/gupea_2077_40588_1.pdf

Okafor, G. (2015). Locational Determinants of US Outward FDI into Sub-Saharan Africa. Journal of Developing Areas, 49(1) , 187-205. Project MUSE, doi:10.1353/jda.2015.0000

Pan, Y. (2003). The inflow of foreign direct investment to China: the impact of country-specific factors. Journal of Business research, 56(10),, 829-833.Retrived from https://pdfs.semanticscholar.org/0cdd/f62fe8257e3391eaa797b$38 f 3 c e f 230 \mathrm{e} 02 \mathrm{eb} . \mathrm{pdf}$

Pradhan, P., \& Saha D. (2011), Determinants of Foreign Direct Investment in SAARC Countries: An Investigation Using Panel VAR Model, Information Management and Business Review.

Saime, S. K. (2009). Home market determinants of FDI outflows from developing and transition economies . Munich Personal RePEc Archive No. 16781, posted 12 .

Schneider F. and Frey, B. (1985). Economic and Political Determinants of Foreign Direct Investment. World Development, vol. 13,, 161-175.

Stock, J. (2012). Introduction to Econometrics, 3rd ed.,. Pearson Education Essex.

Sung, H. \&. Lapan, E. (2000). Strategic Foreign Direct Investment and ExchangeRate Uncertainty. International Economic Review, 41(2), 411-423.

Thomas, D., Grosse, R. (2001). Country-of-origin Determinants of Foreign Direct Investment in an Emerging Market: the Case of Mexico", Journal of International Management, 7: 59-79

Tallman, S. B. (1988). Home country political risk and foreign direct investment in the United States. Journal of International Business Studies, 19(2),, 219-234.

Thangavelu, S. M. and Findlay, C. (2011). The Impact of Free Tade Agrreement on Foreign Direct Investment in the Asia- Pasific Region . In C. Findlay, ASEAN+1 FTAs and Global Valu Chains in East Asia, 112-131. Retrived from https://pdfs.semanticscholar.org/3a67/00e4le7ca16d26c0f8396f7948f2 bc6291ff.pdf

UNCTAD. (2016). WORLD INVESTMENT REPORT. United Nations Conference on Trade And Development.

Wang, C., Hong, J., Kafouros, M., \& Boateng, A. (2012). What drives outward FDI of Chinese firms? Testing the explanatory power of three theoretical frameworks. 425 - 438 .

Wang, H. (2017). Does foreign direct investment affect host-country firms' financial constraints?,'Journal of Corporate Finance, Elsevier, vol. 45(C), pp. 522-539. 
Williams, D. A. (2009). Determinants of Outward Foreign Direct Investments from Small Island Developing States . American Journal of Economics and Business Administration 1 (2) 47-56. retrived from http://thescipub.com/ pdf/10.3844/ajebasp.2009.47.56

Yarbrough, B. V. and Yarbrough R. M. (2002) The World Economy: Trade and Finance, SouthWestern College Publishers.

\section{Appendix A. List of variables and sources of data}

\begin{tabular}{|l|c|c|c|}
\hline Variables & Proxy for & Measuring & Source \\
\hline OFDI & FDI outflows & (\% of GDP) & World Development Indicators \\
\hline MS & Market size & GDP per capita (US dollar) & International Monetary Fund (IMF) \\
\hline INF & Inflation rate & Average consumer prices & International Monetary Fund (IMF) \\
\hline OPEN & Openness & Total trade of GDP & World Development Indicators \\
\hline GE & $\begin{array}{c}\text { Government } \\
\text { Effectiveness }\end{array}$ & $\begin{array}{c}\text { Quality of public and civil } \\
\text { service }\end{array}$ & Global Insight, Global Risk Service \\
\hline D1 & uprising Dummy & $\begin{array}{c}1 \text { if a country experienced } \\
\text { Arab spring otherwise }=0 .\end{array}$ & \\
\hline D2 & Border Dummy & $\begin{array}{c}1 \text { if a country has border } \\
\text { with countries experienced } \\
\text { Arabic spring from 2011 } \\
\text { otherwise }=0,\end{array}$ & \\
\hline D3 & Time Dummy & $\begin{array}{c}\text { Time Dummy } 1 \text { for } \\
\text { period from 2011 to 2016 } \\
\text { otherwise }=0 .\end{array}$ & \\
\hline
\end{tabular}

\section{Appendix B. Testing for multicolienarity}

\begin{tabular}{r|rr} 
Vif \\
\multicolumn{1}{l|}{ Variable } & VIF & $1 /$ VIF \\
\hline Time Dummy & 1.94 & 0.515776 \\
GDPPC & 1.91 & 0.524502 \\
GOVE & 1.79 & 0.557254 \\
TRO & 1.66 & 0.603881 \\
uprisingdu Y & 1.64 & 0.609588 \\
Border2 & 1.45 & 0.691875 \\
INFL & 1.09 & 0.914891 \\
\hline Mean VIF & 1.64 &
\end{tabular}




\title{
Appendix C. Testing for serial correlation
}

\author{
Wooldridge test for autocorrelation in panel data \\ HO: no first-order autocorrelation \\ $\mathrm{F}(1,11)=1.104$ \\ Prob $>E=0.3160$
}

\section{UTJEČE LI ARAPSKO PROLJEĆE NA ODLJEV IZRAVNIH STRANIH ULAGANJA? EMPIRIJSKI DOKAZI IZ ZEMALJA BLISKOG ISTOKA I SJEVERNE AFRIKE}

Sažetak

Cilj rada je empirijski istražiti utjecaj Arapskog proljeća na odljev izravnih stranih ulaganja u dvanaest odabranih zemalja u regiji sjeverne Afrike (Alžir, Tunis, Maroko, Libija, Egipat i Mauritanija) i u regiji Bliskog istoka (Bahrein, Kuvajt, Oman, Libanon, Jordan i Ujedinjeni Arapski Emirati). U radu se koriste panel podaci kako bi se vremenska serija između 2000. i 2016. iskoristila za utvrđivanje odnosa između inozemnih izravnih stranih ulaganja i njegovih odrednica (veličina tržišta, otvorenost trgovine, učinkovitost vlade, inflacija i tri dummy varijable povezane s Arapskim proljećem). Rezultati su pokazali da je utjecaj procjene Arapskog proljeća negativno povezan s odljevima stranih ulaganja u zemljama koje su svjedočile Arapskom proljeću. To znači da sukobi i nestabilnost negativno utječu na odljeve izravnih stranih ulaganja. Rezultati ovog istraživanja otkrivaju da su zemlje koje su izravno pogođene Arapskim proljećem (regija sjeverne Afrike) doživjele veći pad u odljevu izravnih stranih ulaganja nego zemlje koje su bile indirektno pogođene (regija Bliski istok). Kada je uzorak ograničen na sjevernu Afriku, utvrdilo se kako na odljeve izravnih stranih ulaganja može utjecati učinak poslije-arapskog proljeća, dok nema statistički značajnog utjecaja u regiji Bliski istok. Stoga, istraživanje otkriva kako su odljevi izravnih stranih ulaganja u sjevernoafričkim zemljama više određeni učincima Arapskog proljeća nego u zemljama Bliskog istoka.

Ključne riječi: odljevi izravnih stranih ulaganja, Arapsko proljeće, Bliski istok i sjeverna Afrika, analiza panel podataka 